\title{
Optimisation of nursery rearing for megalopa of giant mud crab Scylla serrata (Forskal, 1775)
}

\author{
JOSE ANTONY, C. P. BALASUBRAMANIAN, J. BALAMURUGAN, K. P. SANDEEP, \\ I. F. BIJU AND K. K. VIJAYAN \\ ICAR-Central Institute of Brackishwater Aquaculture, R. A. Puram, Chennai - 600 028, Tamil Nadu, India \\ e-mail:antonyjose@ciba.res.in
}

\begin{abstract}
Three nursery rearing trials were conducted to overcome the inconsistent survival of megalopa of the giant mud crab Scylla serrata (Forskal, 1775) during metamorphosis to crab instar. In the first trial, 3-4 days old megalopa (4.73 mg mean body weight) were stocked in hapas erected in outdoor brackishwater ponds and indoor fiberglass (FRP) tanks at densities of 500 nos. $\mathrm{m}^{-2}$ and 1 no. 1 $^{-1}$ respectively and reared for 15 days using minced clam meat (Meretrix casta) as feed. Outdoor hapas were provided with seaweed, Gracilaria tenuistipitata as shelter. Mean survival rate of crab instar following three consecutive runs were significantly higher $(\mathrm{p}<0.05)$ for megalopa reared in outdoor hapas $(57.7 \pm 2.7 \%)$ over indoor FRP tanks $(24.1 \pm 2.2 \%)$. To ascertain the life stage that yields optimal survival on weaning from indoor hatchery to ponds, zoea 5 (Z5) and megalopa 1-day old (M1), 2-day old (M2), 3-day old (M3) and 4-day old (M4) were reared in hapas for15 days and fed on minced clam meat. Three day and 4-day old megalopa demonstrated significantly higher survival rates $(\mathrm{p}<0.05)$ of $62.3 \pm 3.08 \%$ and $69.6 \pm 2.35 \%$ respectively to crab instar stage at conclusion of the trial. Megalopa (3-4 days old, $5.05 \mathrm{mg}$ mean body weight) were stocked to 1001 tanks (stocking density -1 no. $4 \mathrm{l}^{-1}$ ) and reared for a period of 8 days using different feeds viz., artemia biomass (T1), minced clam meat (T2), crab larvae (T3) and artemia nauplii (T4) in the third trial to evaluate various production parameters. Crab instar conversion rate (number of crab instars/number of megalopa stocked $\times 100)$ was significantly higher $(\mathrm{p}<0.0001)$ for megalopa fed using artemia biomass $(\mathrm{T} 1)$ and minced clam meat $(\mathrm{T} 2)$ at $74.66 \pm 5.81 \%$ and $72.00 \pm 2.30 \%$ respectively. Results of the present study indicate that, high density rearing $\left(500 \mathrm{no}^{-2}\right)$ of megalopa (3-4 days old) in outdoor hapas provided with seaweed refuge for short periods (15 days) would yield higher survival rate to crab stage. Nursery rearing of megalopa in ponds reduces the hatchery phase in mud crab larval rearing and maximise production of crab instars.
\end{abstract}

Keywords: Crab instar, High density, Megalopa, Nursery rearing, Scylla serrata, Survival

\section{Introduction}

Mud crab aquaculture is an emerging economic activity in the coastal areas of many south-east Asian countries, including India, and it is the focus of diversification in brackishwater aquaculture (Balasubramanian et al., 2016). High price, good demand and excellent export potential for mud crabs coupled with the ease of farming have resulted in expansion of mud crab aquaculture. Among the four species of portunid mud crabs as described by Keenan et al. (1998), only two species are present in Indian waters (Balasubramanian et al., 2016). The giant mud crab, Scylla serrata is the most preferred species for mud crab aquaculture owing to its larger size, higher price and faster growth rate (Williams and Primavera, 2001). Farming of S. serrata in India is mostly dependent on wild caught juvenile crabs and the recent boom in the industry has resulted in decline of the fishery for mud crabs due to overfishing of seed stock from natural habitats (Thampi Sam Raj et al.,
2015). Sustainable development of mud crab aquaculture inevitably requires hatchery produced seed and nursery rearing to produce juvenile crabs for farming. The hatchery technology for producing $S$. serrata megalopa and instar has evolved through the studies of Heasman and Fielder (1983), Marichamy and Rajapackiam (1992) and Quinitio et al. (2001) and has been standardised to near commercial levels at the Aquaculture department (AQD) of Southeast Asian Fisheries Development Center (SEAFDEC), Philippines (Quinitio and Parado-Estepa, 2003; Quinitio and Parado-Estepa, 2008).

The larval phase of $S$. serrata involves five zoeal stages (3-4 days each) and one megalopa stage ( 7 to 10 days) before metamorphosis to crab instar (Ong, 1964). Megalopa possess chelae or pincers to capture prey (Ong, 1964; Heasman and Fielder, 1983) and is sometime referred to as early post-larvae (Mann et al., 2007). High activity, possession of chelae and free swimming nature of megalopa makes it highly predatory in nature causing 
cannibalism of zoea and other megalopa resulting in poor survival to crab stage (Quinitio and Parado-Estepa, 2000; Rodriguez et al., 2001). The survival rate of megalopa to crab instar is highly variable in commercial/experimental mud crab hatcheries (Quinitio and Parado-Estepa, 2000; Rodriguez et al., 2001; Hamasaki et al., 2002; Mann et al., 2007).

Frequently, megalopa of mud crab fails to metamorphose into crab instar in the hatchery facility (Hamasaki et al., 2002). In this paper, we have compared the survival rate of megalopa in two rearing systems i.e., indoor tanks and hapa erected in the earthen ponds. Further, we have evaluated the life stages (zoea 5 and megalopa of 1 to 4 days old) that yield the best survival when weaned to earthen ponds. In order to optimise feeding during nursery rearing, the survival rate and other production parameters of megalopa fed on different feeds (artemia nauplii, artemia biomass, minced clam meat and crab larvae) was also determined.

\section{Materials and methods}

The present study was carried out at the mud crab hatchery and brackishwater ponds at the Muttukadu Experimental Station (MES) of the ICAR-Central Institute of Brackishwater Aquaculture (ICAR-CIBA) at Muttukadu, Tamil Nadu. Adult females of S. serrata (mean body weight $-489 \pm 27.8 \mathrm{~g}$ ) in advanced stages of maturity were obtained from the wild for the production of juvenile crabs. Seed production of $S$. serrata followed Quinitio et al. (2001) and Quinitio and Parado-Estepa (2003) with minor modifications. The mature female crabs were disinfected with $150 \mathrm{ppm}$ formalin and $0.1 \mathrm{ppm}$ treflan on arrival and were placed in 5001 fiber glass (FRP) broodstock cum incubation tanks with a plastic tub (45 cm dia and $12 \mathrm{~cm}$ deep) containing sand at its bottom. Unilateral eyestalk ablation of the female crabs was carried out a week after arrival at the hatchery. The crabs were fed on low valued fish biomass and clam meat (Meretrix casta) in equal proportions at $5-10 \%$ of the body weight. Water exchange in the brood tanks were carried out twice a day using filtered seawater (salinity: $29.3 \pm 0.4$ ) at the rate of $80 \%$ prior to feeding. The plastic tub containing sand was removed from the brood tank after spawning when the crab became berried. The feeding rate of the berried crabs was halved and by the $6^{\text {th }}$ day after spawning, feeding was stopped. Hatching occurred 9 to 10 days post-spawning (temperature $28.5 \pm 0.5^{\circ} \mathrm{C}$ ) in the same broodstock tank. Zoeae were collected within an hour post-hatching, estimated using the volumetric method and were stocked to 50001 larval rearing tank (LRT) at a stocking density of 50 zoeae $1^{-1}$. Zoeae were fed with the rotifer Brachionus rotundiformis grown on marine Chlorella sp. at the rate of 20 rotifers $\mathrm{ml}^{-1}$ in the
LRT. Chlorella sp. was also added in to LRTs at 1 lakh cells $\mathrm{ml}^{-1}$ for water conditioning and as feed for the rotifers. Freshly hatched artemia nauplii was fed to the zoea at 1 no. $\mathrm{ml}^{-1}$ starting from day 7 or 8 based on the temperature and larval progression. Co-feeding using rotifer was continued till day 10 in order to minimise the effects of asynchronous metamorphosis in crab zoea. The density of artemia nauplii was increased to 3-5 no. $\mathrm{ml}^{-1}$ starting from zoea 5 and continued to the megalopa stage. Megalopa stage was first observed in 16 to 17 days of larval rearing and most of the zoea 5 metamorphosed to megalopa in the next 2 to 3 days. The megalopa were fed on artemia nauplii $\left(5\right.$ no. $\left.\mathrm{ml}^{-1}\right)$ for the initial 3-4 days post-metamorphosis, following which the feeding regime was changed based on the objectives of the trials. No water exchange was done in the LRTs during the first four days and 30 to $50 \%$ of the water was exchanged on alternate days after removal of dead larvae and uneaten feed subsequently. Filtered seawater was used during the hatchery phase so as to maintain the salinity, temperature and $\mathrm{pH}$ at $29.3 \pm 0.4 \mathrm{ppt}, 28.5 \pm 0.6^{\circ} \mathrm{C}$ and $8.11 \pm 0.02$ respectively. Water level in the LRTs were gradually increased to 25001 from the initial level of 10001 by the time megalopa stage was attained so as to ensure thinning of the larvae. Megalopa and advanced larvae (2-3 day old Zoea 5) produced in the hatchery were used in the experimental trials for optimising the nursery rearing of megalopa. The present study consisted of eight $(n=8)$ successful hatchery runs using twenty-two $(n=22)$ females to rear zoea till megalopa stage. A few hatchery runs were discarded at the beginning and at midst of the cycle due to poor larval quality and high larval mortality due to disease and nutritional issues. All the megalopa and advanced larvae used in any single experimental trial or its subsequent runs were obtained from a single brood.

\section{Trial 1: Evaluation of nursery rearing systems}

Three to four days old megalopa produced in the hatchery were subjected to two different nursery rearing treatments i.e., hapas (net cages) installed in brackishwater ponds and indoor FRP tank. The hapas had dimensions of $2 \times 1 \times 1 \mathrm{~m}$ with a mesh size of $0.5 \mathrm{~mm}$ and were made of polyethylene (PE) monofilament. The hapas were closed on all six sides and possessed a zip arrangement on the top panel for stocking and feeding purposes. The brackishwater ponds at MES being undrainable structures, were treated with bleaching powder at $10 \mathrm{ppm}$ active chlorine concentration for disinfection and removal of other fishes and crabs which can damage the hapas. The ponds had an area of $200 \mathrm{~m}^{2}$ and were $1.5 \mathrm{~m}$ deep. Pond fertilisation followed a modified Biswas et al. (2012) procedure using urea (20 kg ha-1), single super phosphate $\left(20 \mathrm{~kg} \mathrm{ha}^{-1}\right)$ and 
fermented molasses (20 1 ha $^{-1}$ ) cum rice bran mix $\left(20 \mathrm{~kg} \mathrm{ha}^{-1}\right)$ diluted in 2001 pond water (organic juice) and applied in the early morning hours. The dose was repeated until transparency in the pond reached a level of 30 to $35 \mathrm{~cm}$. The hapas were erected in the ponds using casuarina poles driven to the pond bed and tied with polypropylene ropes. The bottom panel of the hapas were held $20 \mathrm{~cm}$ above the pond bottom without contact with the mud and the top panel was provided a $40 \mathrm{~cm}$ free board above the water surface. Three such hapas were erected in a single pond for the study. Each of these hapas were stocked with $10 \mathrm{~kg}$ of live seaweed, Gracilaria tenuistipitata as shelter for the larvae. The seaweeds were collected from the adjacent brackishwater lake and were washed and disinfected with $100 \mathrm{ppm}$ potassium permanganate solution for $5 \mathrm{~min}$ prior to stocking in to the hapas. The indoor circular FRP tanks (5000 1) in triplicate were disinfected using mild acid and filled with filtered seawater to $1000 \mathrm{l}$. The tanks were provided with floating $(30 \mathrm{~cm} \times 15 \mathrm{~cm})$ and submerged shade net pieces (30 $\mathrm{cm} \times 30 \mathrm{~cm}$ with a stone at its centre) to increase the surface area (Quinitio and Parado-Estepa, 2008; ParadoEstepa et al., 2015). Megalopa (mean body weight or BW $-4.73 \pm 0.17 \mathrm{mg}$ ) were released in to the two nursery rearing treatments i.e., hapas installed in brackishwater ponds and indoor FRP tanks at a stocking density of 500 nos. $\mathrm{m}^{-2}$ (1000 megalopa per hapa) and 1 no. $\mathrm{l}^{-1}$ (1000 megalopa per tank) respectively during the late evening hours. The megalopa were randomly distributed to the two treatment groups which were maintained in triplicate, thus following a completely randomised design. The megalopa destined for the ponds were acclimatised to the pond conditions prior to release in to the hapas. Artemia biomass (total length, $\mathrm{TL}=4-5 \mathrm{~mm}$ ) was added to the tanks and hapas prior to release of megalopa at the rate of 5 nos. per megalopa and the same feeding was repeated on the day of stocking. The treatment groups were thereafter fed only on minced clam meat (M. casta) at $100 \%$ of the biomass divided in to four equal feeding session at 0900 , 1300,1500 and $1800 \mathrm{hrs}$. Water exchange in the indoor tanks were carried out daily at the rate of $60 \%$ prior to the first feeding in the day and replaced with filtered seawater. The hapas installed in the ponds were brushed once in two days to maximise water movement. Water level in the pond was maintained at $80 \mathrm{~cm}$ by pumping from an adjacent brackishwater tube well and $30 \%$ of the pond water was exchanged once in a week. The study was carried out for a period of 15 days wherein the same feeding rate based on the initial biomass was continued. Crab instars were individually counted at the end of the experiment by retrieving the hapas and emptying the tanks. The final observations were expressed in terms of the mean survival rate of crab instars in the treatments after three successive runs. The carapace width $(\mathrm{CW})$ and body weight $(\mathrm{BW})$ of crab juveniles were also recorded at the end of the study.

Trial 2: Effect of early weaning of advanced larvae from indoor hatchery to earthen pond

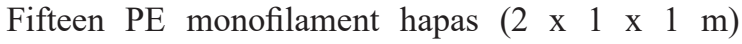
of mesh size $0.5 \mathrm{~mm}$ were erected in three $200 \mathrm{~m}^{2}$ brackishwater ponds ( 5 hapas per pond) to stock the larvae. The pond preparation and erection of hapas followed the same procedure as in the first trial. Hapas were loaded with $10 \mathrm{~kg}$ of live seaweed (G. tenuistipitata) after disinfection. The present trial consisted of five treatments namely, zoea 5 (Z5) and megalopa of 1 day (M1), 2 day (M2), 3 day (M3) and 4 day (M4) old stocked to hapas erected in earthen ponds at 500 no. $\mathrm{m}^{-2}(1000$ megalopa per hapa). Megalopa of 1 day old (M1) refers to the freshly metamorphosed megalopa. The zoea 5 and variably aged megalopa were obtained from a single brood and stocked to separate hapas in a sequential manner i.e., treatments were stocked on consecutive days according to the larval age. Each treatment group was randomly distributed to three separate hapas (triplicate) and a completely randomised design was followed. The zoea and megalopa were collected in the morning and held in separate tanks prior to acclimatisation and release to the hapas. Artemia nauplii were added to the hapas at 10 nos. per larva on the first day following which minced clam meat (M. casta) was fed at $100 \%$ of the biomass divided in to four equal feeding sessions as in the first trial. The hapas were brushed once in two days to ensure circulation and organic juice application was carried once every week to maintain the transparency at $30-35 \mathrm{~cm}$. The water depth in the pond was maintained through pumping from a brackishwater tube well. The study continued for 15 days, at the end of which the hapas were retrieved and the crab instars were individually counted. The performance of the different treatments was expressed in terms of survival rate of the crab instars at the end of 15 days. The $\mathrm{CW}$ and BW of crab juveniles in different treatment groups were also recorded at the end of the study.

\section{Trial 3: Megalopa feeding experiment}

Hatchery produced megalopa (3-4 days old, BW $5.05 \pm 0.26 \mathrm{mg}$ ) were stocked in to twelve dark coloured 1001 FRP tanks@1 megalopa $41^{-1}$ (25 megalopa per tank) during the morning hours. Each of the tanks were provided with two numbers of submerged shade net pieces (black, $30 \times 30 \mathrm{~cm}$ ) with a stone wrapped to its centre resulting in a flower like resemblance (Quinitio and Parado-Estepa, 2008; Parado-Estepa et al., 2015). The tanks were filled with filtered seawater similar to that used for the larval rearing. The study consisted of four feeding treatments i.e., Artemia biomass (T1), minced clam meat (T2), crab 
larvae (T3) and artemia nauplii (T4) for nursery rearing of megalopa. The artemia nauplii were hatched from artemia cyst (PRO $80^{\circledR}$, OSI, Utah, USA) and the nauplii were reared on the algae Thalassiosira weissflogii for a period of 7-10 days to obtain 8-10 mm TL artemia biomass (T1). Previous studies in the hatchery indicated that megalopa had difficulty preying on fast moving adult artemia. Artemia biomass was therefore harvested, chopped and fed to the megalopa. The clam, M. casta was collected from adjacent lake (Muttukadu Lake) and depurated for a day in running seawater. The clam meat (T2) was finely chopped and sieved before being washed and fed to the animals. Freshly hatched zoeae (zoea 1) of S. serrata were harvested and frozen to be used as a treatment diet for nursery rearing of megalopa. The frozen crab larvae (T3) were thawed and fed to the animals. The treatment diets were individually fed to the experimental units (100 1 tanks with 25 megalopa) in triplicate. All the megalopa used in the study were obtained from a single brood. The feeding treatments viz., Artemia biomass (T1), minced clam meat (T2) and crab larvae (T3) were fed at the rate of $100 \%$ of the biomass added in a single feeding session post-water exchange. Artemia nauplii (T4) were fed at the rate of 5 nos. $\mathrm{ml}^{-1}$ post-water exchange in a single feeding session. Water was exchanged at the rate $70 \%$ in all the tanks before feeding and replaced with filtered seawater. At the end of 8 days, the tanks were emptied and all the crab instars and remaining megalopa were individually counted. The results of the trial were expressed in terms of final survival rate (number of crab instars and megalopa/ number of megalopa stocked $\times 100$ ), crab instar conversion rate (number of crab instars/number of megalopa stocked $\times 100$ ), megalopa percentage (number of megalopa remaining in the tank/number of megalopa stockedx100) and the length-weight data of the crab instars.

Water quality parameters namely, salinity (ppt), temperature $\left({ }^{\circ} \mathrm{C}\right), \mathrm{pH}$ and dissolved oxygen (ppm) were recorded twice daily (0900 and $1600 \mathrm{hrs)} \mathrm{using} \mathrm{a} \mathrm{multi-}$ parameter probe (YSI Professional plus, YSI Incorporated, USA). Total ammonia nitrogen (TAN) and nitrite-nitrogen $\left(\mathrm{NO}_{2}-\mathrm{N}\right)$ were measured once every three days using a photometric test kit (Spectroquant ${ }^{\circledR}$, Merck, Germany). The survival rate (\%) was arcsine transformed prior to statistical analysis. The normality of the data and homogeneity of variances were tested using Shapiro-Wilk's W test and Levene's test respectively. The two treatments in the first trial were compared using independent two sample $t$ test $(\mathrm{p}<0.05)$. The survival rate, crab instar conversion rate, megalopa percentage, carapace width $(\mathrm{CW})$ and body weight $(\mathrm{BW})$ of the treatment groups in trials two and three were compared using one-way analysis of variance (ANOVA) $(\mathrm{p}<0.05)$. The treatment means were compared using Tukey's multiple comparison tests at 0.05 level of significance. The statistical analysis was performed using SPSS for windows, version 16.0 (SPSS Inc., Chicago, IL, USA).

\section{Results}

The survival rate of megalopa to crab instar was significantly higher in hapas erected in earthen pond compared to those reared in indoor FRP tanks $(57.7 \pm 2.7 \%$ vs $24.1 \pm 2.2 \%$; $<<0.05$; Fig. 1). The mean BW (0.34 g) and $\mathrm{CW}(9.5 \mathrm{~mm})$ of the crab juveniles, however, in the two rearing systems at the end of 15 days did not vary significantly $(p>0.05)$. Water quality parameters in the ponds and indoor tanks were within tolerable limits for mud crab megalopa and instar (Table 1).

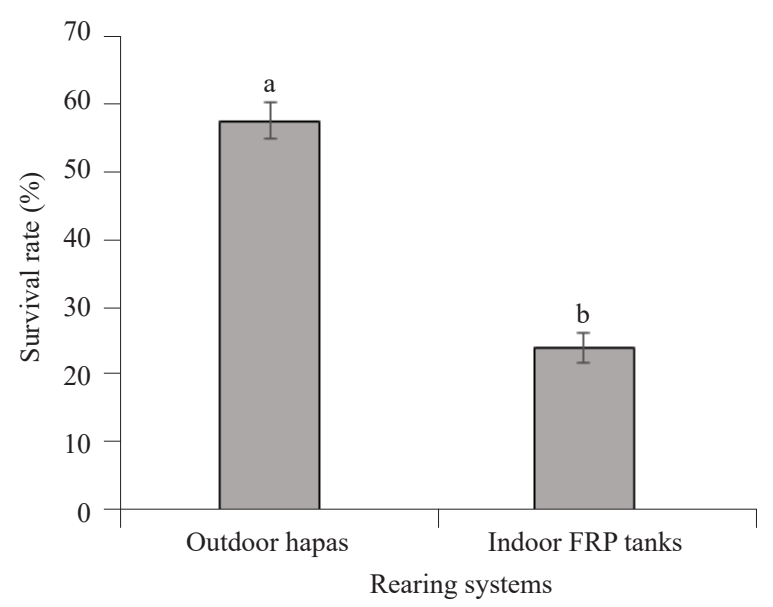

Fig. 1. Mean survival rate (following three runs) of megalopa to crab instars post-nursery rearing in outdoor hapas and indoor FRP tanks at the end of 15 days

Megalopa of 3-day (M3) and 4-day (M4) old demonstrated significantly higher survival rates $(62.3 \pm 3.08 \%$ and $69.6 \pm 2.35 \% ; \mathrm{p}<0.05)$ compared to zoea 5 (Z5) and 1-day (M1) and 2-days old (M2) megalopa (Fig. 2). The lowest survival rate was observed when zoea $5(2.0 \pm 0.3 \%)$ was weaned to hapas erected in ponds followed by early megalopa of 1-day $(4.8 \pm 0.6 \%)$ and 2-days old (13.6 $\pm 1.3 \%)$. The mean BW $(\sim 0.28 \mathrm{~g})$ and $\mathrm{CW}$ $(\sim 8.3 \mathrm{~mm})$ of the crab juveniles did not vary significantly across the treatments at the end of the trial $(p>0.05)$. Mean values of water quality parameters in the three ponds during the trial are shown in Table 1.

The crab instar conversion rate (\%) of megalopa fed on different feeding treatments namely, artemia biomass (T1), minced clam meat (T2), crab larvae (T3) and artemia nauplii (T4) was observed to be significantly different at the end of 8 days (Table $2 ; \mathrm{p}<0.05$ ). The feeding treatments, artemia biomass (T1) and minced clam meat (T2) resulted in significantly higher megalopa to crab instar conversion 
Table 1. Mean water quality parameters (mean $\pm \mathrm{SE}$ ) in ponds and indoor tanks during experimental trials on nursery rearing of S. serrata megalopa

\begin{tabular}{|c|c|c|c|c|}
\hline \multirow{2}{*}{ Parameter } & \multicolumn{2}{|c|}{$1^{\text {st }}$ trial (Hapa $v s$ tanks) } & \multirow{2}{*}{$\begin{array}{l}2^{\text {nd }} \text { trial (life stages) } \\
\text { Ponds }\end{array}$} & \multirow{2}{*}{$\begin{array}{l}3^{\text {rd }} \text { trial (Feeding tria } \\
\text { Indoor tanks }\end{array}$} \\
\hline & Ponds & Indoor tanks & & \\
\hline Salinity (ppt) & $24.5 \pm 0.9$ & $29.8 \pm 0.04$ & $25.1 \pm 0.4$ & $28.2 \pm 0.02$ \\
\hline Temperature $\left({ }^{\circ} \mathrm{C}\right)$ & $29.2 \pm 0.7$ & $28.5 \pm 0.5$ & $29.7 \pm 0.6$ & $28.7 \pm 0.1$ \\
\hline $\mathrm{DO}(\mathrm{ppm})$ & $>4 \mathrm{ppm}$ & $>4 \mathrm{ppm}$ & $5.1 \pm 0.2$ & $>4 \mathrm{ppm}$ \\
\hline $\mathrm{pH}$ & $7.8 \pm 0.07$ & $8.1 \pm 0.03$ & $7.8 \pm 0.02$ & $8.16 \pm 0.03$ \\
\hline TAN (ppm) & $0.10 \pm 0.01$ & $0.08 \pm 0.01$ & $0.11 \pm 0.03$ & $0.03 \pm 0.01$ \\
\hline $\mathrm{NO}_{2}-\mathrm{N}(\mathrm{ppm})$ & $0.14 \pm 0.06$ & $0.09 \pm 0.02$ & $0.18 \pm 0.09$ & $0.06 \pm 0.03$ \\
\hline
\end{tabular}

DO - Dissolved oxygen, TAN - Total ammonia nitrogen, $\mathrm{NO}_{2}-\mathrm{N}$ - Nitrite nitrogen

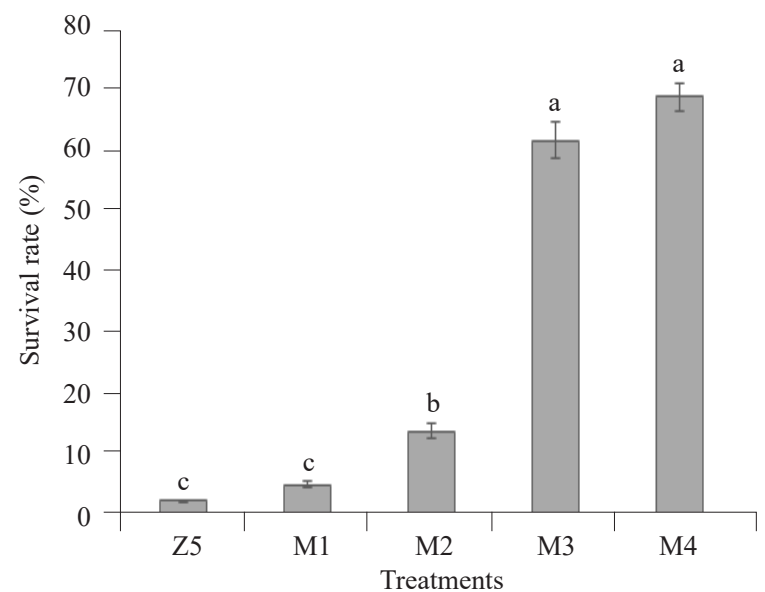

Fig. 2. Survival rate (\%) of zoea 5 (Z5) and variably aged megalopa to crab juveniles at the end of 15 days of nursery rearing in hapas erected in earthen ponds. M1: 1 day old megalopa, M2: 2 days old megalopa, M3: 3 days old megalopa, M4: 4 days old megalopa
Mean survival rate of $57 \%$ was observed when megalopa were reared at high densities $\left(500\right.$ no. $\left.\mathrm{m}^{-2}\right)$ in hapas erected in brackishwater ponds. Mann et al. (2007) observed a survival rate of $60 \%$ when megalopa were reared for 11 days in net cages to crab instar stage (C1) at high densities of 700-2300 nos. $\mathrm{m}^{-2}$. Results of this trial are in agreement with previous data reported by Mann et al. (2007). Mean survival rate of crab instar in indoor tanks $(24 \%)$ as observed in this trial was similar to survival rates (26-32\%) previously reported by Quinitio et al. (2001) for megalopa reared in tanks. Survival rate of crab juveniles was higher for megalopa reared at 24 ppt (ponds) than those at $30 \mathrm{ppt}$ (indoor tanks) in the present trial. Similarly, Quinitio et al. (2001) reported higher survival rate from megalopa to crab juveniles when larvae were reared at lower salinity of $26 \mathrm{ppt}$ compared to oceanic water at 34 ppt. Inability of the crab larvae to shed exoskeleton during moulting is often encountered during the conversion

Table 2. Crab instar conversion rate (\%), percentage of megalopa and final survival rate (\%) of megalopa fed using different feeds at the end of 8 days

\begin{tabular}{|c|c|c|c|c|c|c|}
\hline Parameters & T1 (Artemia biomass) & T2 (Clam meat) & T3 (Crab larvae) & T4 (Artemia nauplii) & F value & $\mathrm{p}$ value \\
\hline Crab instar conversion rate (\%) & $74.66 \pm 5.81^{\mathrm{a}}$ & $72.00 \pm 2.30^{\mathrm{a}}$ & $48.00 \pm 6.92^{b}$ & $10.66 \pm 3.52^{\mathrm{c}}$ & 35.31 & $<0.0001$ \\
\hline Megalopa (\%) & $2.66 \pm 1.33^{\mathrm{a}, \mathrm{b}}$ & $1.33 \pm 1.33^{\mathrm{a}, \mathrm{b}}$ & $8.0 \pm 2.30^{\mathrm{a}}$ & $0^{\mathrm{b}}$ & 5.53 & 0.023 \\
\hline Final survival rate $(\%)$ & $77.33 \pm 5.81^{\mathrm{a}}$ & $73.33 \pm 2.66^{\mathrm{a}}$ & $56.00 \pm 8.32^{\mathrm{a}}$ & $10.66 \pm 3.52^{\mathrm{b}}$ & 30.43 & 0.0001 \\
\hline
\end{tabular}

Different superscript letters within the same row indicate significant difference $(\mathrm{p}<0.05)$

(74.66 $\pm 5.81 \%$ and $72.00 \pm 2.30 \%$ respectively, $\mathrm{p}<0.05)$. However, the mean BW ( 0.18 g) and CW ( $\sim 5.5 \mathrm{~mm})$ of the crab instars in different treatment groups did not vary significantly $(p>0.05)$. The water parameters in the experimental tanks were maintained optimally during the experimental duration (Table 1).

\section{Discussion}

Survival rate of crab instar in the present study was significantly higher for megalopa reared in hapas (net cages) compared to those reared in indoor FRP tanks. from zoea 5 to megalopa resulting in high mortality and the phenomenon is termed moult death syndrome (Fielder and Heasman, 1999; Williams et al., 1999). Genodepa et al. (2004) and Holme et al. (2006) reported the occurrence of moult death syndrome also during the conversion of megalopa to crab instar (C1). High mortality observed during the moulting process is often attributed to poor nutritional status of the larvae (Williams et al., 1999). Higher survival rate of crab instar for megalopa reared in ponds $(57 \%)$ than those stocked in tanks $(24 \%)$ may be due to availability of natural zooplankton apart from the 
minced clam meet provided, ensuing better nutritional status for larvae in ponds.

Rodriguez et al. (2001) reported survival rates ranging from 48 to $53 \%$ for megalopa reared to crab juveniles in $20 \mathrm{~m}^{2}$ net cages at densities of 10-30 nos. $\mathrm{m}^{-2}$. Results of this study are in agreement with the observations of Rodriguez et al. (2001), despite using smaller hapas (area $2 \mathrm{~m}^{2}$ ) and higher stocking density of 500 nos. $\mathrm{m}^{-2}$. Quinitio and Parado-Estepa (2003) recommended a maximum stocking density of 50-70 nos. $\mathrm{m}^{-2}$ during nursery rearing of megalopa in net cages. Several studies have reported high rate of cannibalism resulting in poor survival during nursery rearing of megalopa (Jamari, 1992; Keenan, 1999; Li et al., 1999; Quinitio et al., 2001; Genodepa et al., 2004). Higher survival rate of megalopa to crab juveniles in ponds despite high stocking density may be due to the large volume of live seaweed ( $G$. tenuistipitata) stocked in the hapas providing greater refuge to megalopa. Selective preference of $S$. serrata juveniles for seagrass habitats has been observed by Webley et al. (2009) during laboratory trials and suggested that such habitat selection may be positively correlated with the survival rates. Dense branching of fronds in Gracilaria sp. resembles seagrass beds and may have minimised negative interaction between megalopa resulting in higher survival rate. Utilisation of Gracilaria seaweeds during tank based nursery rearing of $S$. serrata megalopa has also been suggested by Quinitio et al. (2001).

Low stocking density of megalopa during nursery rearing as suggested by Rodriguez et al. (2001) and Quinitio and Parado-Estepa (2003) is suitable to produce bigger sized crab juveniles that can directly be used for growout or pre-growout operations. However, rearing of megalopa in tanks at low stocking densities (1 to 2 no. $\mathrm{r}^{-}$) within the hatchery resulted in significantly lower survival rates $(24 \%)$ and consumption of large volume of tanks apart from extending the hatchery phase in mud crab seed production. Nursery rearing of megalopa in hapas erected in ponds yield better results along with reduction in the hatchery phase ensuring effective utilisation of indoor tanks for rearing of zoea. Overall, better production characteristics of megalopa reared in ponds may be the cumulative effect of lower salinity ( $24 \mathrm{ppt}$ ), availability of live feed, larger surface area provided by seaweed substratum and shading effect in the brackishwater environment due to high primary productivity.

Survival rate of megalopa to crab juveniles at the end of 15 days of hapa based nursery rearing was significantly higher for megalopa of 3 days (M3) and 4 days (M4) old respectively. Stocking of Zoea 5 (Z5) and 1 day (M1) and 2 days (M2) old early megalopa in outdoor hapas resulted in poor survival to the crab stage, indicating high mortality on early exposure to pond environment. Mann et al. (2007) reported poor and variable survival rates for early megalopa subjected to nursery rearing. Rodriguez et al. (2001) obtained high survival rate from megalopa to crab stage when megalopa of 3-5 days old were stocked in net cages erected in ponds. The results of this study are consistent with the findings of Rodriguez et al. (2001). Ascertaining the life stage that yields maximum survival when transferred to ponds is critical for reduction in the hatchery phase of mud crab seed production. Paradoestepa and Quinitio (1999) reported that zoea 5 can be acclimatised to different salinities and the highest survival until megalopa stage was obtained at 28 ppt with no significant difference at 24 and $32 \mathrm{ppt}$. Poor survival rate of zoea 5 and early megalopa to crab stage, therefore cannot be linked to the differences in salinities between the pond (25 ppt) and the hatchery (29-30 ppt). Genodepa et al. (2004) observed the occurrence of high mortality rates in early megalopa stage when the animal has freshly metamorphosed from the last zoeal stage. Results of this study are consistent with the earlier reports of Genodepa et al. (2004) and Mann et al. (2007). Poor survival rate of zoea 5 (Z5) and early megalopa (M1 and M2) may be attributed to the delicate nature of the larvae which cannot survive the stress in the pond environment. In order to reduce hatchery phase in mud crab seed production and maximise utilisation of tanks for rearing of zoea, 3-4 days old megalopa should be shifted to net cages erected in brackishwater ponds.

Crab instar conversion rate, percentage of megalopa and final survival rate of megalopa fed on different live and unprocessed feeds were observed to be significantly different at the end of 8 days. In order to identify the feeds that results in megalopa to crab instar conversion within the shortest rearing period, the experimental duration was restricted to 8 days. Ong (1964) studied the life cycle of S. serrata and reported a megalopa phase of 7-10 days. Since, 3-4 days old megalopa from the hatchery were used in this trial, the experiment duration of 8 days would adequately identify the nursery feeds that yield superior crab instar conversion and synchronisation of metamorphosis to crab stage. Significantly higher crab instar conversion and survival rates were observed when megalopa were fed using artemia biomass (T1:74.6\%) and minced clam meat (T2:72\%). Higher survival rates obtained, despite megalopa being reared in indoor conditions is probably an effect of the feeding and low stocking density ( 1 no. $4 \mathrm{l}^{-1}$ or $0.25 \mathrm{no}^{\mathrm{l}^{-1}}$ ) employed in the trial. The use of molluscs like green mussel (Quinitio et al., 2001), brown mussel (Rodriguez et al., 2001; 2007), snail meat (SEAFDEC/AQD, 2010) and other bivalves as feed for megalopa has been reported in the past. Furthermore, observations on the survival rate of megalopa fed using 
minced clam meat in tanks and net cages indicate that $M$. casta is suitable for nursery rearing of mud crab. Williams et al. (1999) reported a survival rate of 38 and $46 \%$ when megalopa were fed using artemia nauplii, and enriched artemia nauplii respectively in indoor trials. However, the use of freshly hatched artemia nauplii as feed for 3-4 days old megalopa yielded only $10 \%$ survival in this trial. Use of artemia nauplii as nursery feed was previously evaluated during regular hatchery cycles at the mud crab hatchery and the survival rates observed was poor compared to artemia biomass and minced clam meat. Quinitio and Parado-Estepa (2003) have also suggested the use of artemia biomass for tank based nursery rearing of megalopa. The use of frozen crab larvae (T3) as feed resulted in higher percentage of megalopa at the end of the trial and an intermediate survival rate of $48 \%$ to crab instar stage. Higher percentage of non-metamorphosed megalopa and intermediate survival suggest that frozen crab larvae may not be an ideal feed for the megalopa. However, taking note of the positive observations of using crab larvae as feed for megalopa, further trials may be conducted to evaluate the survival and conversion rates when live crab larvae of $S$. serrata or other crab species (Zoea 1) are used as nursery feed.

Results of this study clearly showed that the production of crab instar can be increased through nursery rearing of megalopa at high densities (500 no. $\mathrm{m}^{-2}$ ) in net cages installed in brackishwater ponds with adequate feeding using locally available unprocessed feeds and live seaweed as refuge for short periods (15 days). Following this, the animals may be released to ponds or bigger hapas for further nursery rearing. Nursery rearing at high stocking densities is not recommended for periods exceeding 15 days, as interaction between the animals would offset a higher rate of cannibalism resulting in significant decline in the survival rate. High density rearing of megalopa may therefore, be carried out when the objective is to maximise the production of crab instars. The study also provides valuable information pertaining to the life stage yielding maximum survival and nursery feeds for optimisation of nursery rearing for megalopa. Hapa based high density nursery rearing of megalopa in ponds would shorten the hatchery phase in the mud crab seed production to 15-18 days ensuing better economics of the hatchery operation.

\section{Acknowledgements}

The authors wish to thank Dr. C. Gopal, former Head, Crustacean Culture Division (CCD), ICAR-CIBA, Chennai for his encouragement and assistance. We thank the personnel at the mud crab hatchery for their assistance during the hatchery and field trials. This study was conducted as part of the Institute research project of crustacean culture division of ICAR-CIBA with financial assistance from the ICAR, New Delhi.

\section{References}

Balasubramanian, C. P., Cubelio, S. S., Mohanlal, D. L., Ponniah, A. G., Kumar, R., Bineesh, K. K., Ravichandran, P., Gopalakrishnan, A., Mandal, A. and Jena, J. K. 2016. DNA sequence information resolves taxonomic ambiguity of the common mud crab species (Genus Scylla) in Indian waters. Mitochondrial DNA Part A: DNA Mapping, Sequencing, and Analysis, 27(1): 270-275. doi: 10.3109/19401736.2014.892076.

Biswas, G., De, D., Thirunavukkarasu, A. R., Natarajan, M., Sundaray, J. K., Kailasam, M., Kumar, P., Ghoshal, T. K., Ponniah, A. G. and Sarkar, A. 2012. Effects of stocking density, feeding, fertilisation and combined fertilisationfeeding on the performances of striped grey mullet (Mugil cephalus L.) fingerlings in brackishwater pond rearing systems. Aquaculture, 338: 284-292. doi.org/10.1016/j. aquaculture.2012.02.004.

Fielder, D. R. and Heasman, M. P. 1999. Larval rearing and nursery production. In: Keenan, C. P. and Blackshaw, A. (Eds.), Mud crab aquaculture and biology, Proceedings of an international scientific forum, 21-24 April 1997. ACIAR proceedings, vol. 78, ACIAR, Canberra, Australia, p. 209-214.

Genodepa, J., Zeng, C. and Southgate, P. C. 2004. Preliminary assessment of a microbound diet as an Artemia replacement for mud crab, Scylla serrata, megalopa. Aquaculture, 236(1-4): 497-509. DOI: 10.1016/j.aquaculture.2004. 02.007 .

Hamasaki, K., Suprayudi, M. A. and Takeuchi, T. 2002. Mass mortality during metamorphosis to megalopa in the seed production of mud crab Scylla serrata (Crustacea, Decapoda, Portunidae). Fish. Sci., 68(6): 1226-1232. doi. org/10.1046/j.1444-2906.2002.00559.x.

Heasman, M. P. and Fielder, D. R. 1983. Laboratory spawning and mass rearing of the mangrove crab, Scylla serrata (Forskal), from first zoea to first crab stage. Aquaculture, 34: 303-316. doi.org/10.1016/0044-8486(83)90210-7.

Holme, M. H., Zeng, C. and Southgate, P. C. 2006. Use of microbound diets for larval culture of mud crab, Scylla serrata. Aquaculture, 257: 482-490. doi.org/10.1016/j. aquaculture.2006.03.014.

Jamari, Z. B. 1992. Preliminary studies on rearing the larvae of the mud crab (Scylla serrata) in malaysia. In: Angell, C. A. (Ed.), The mud crab, a report on the Seminar convened in Surat Thani, Thailand, 5-8 November 1991. Bay of Bengal Programme, Madras, India, p. 143-147.

Keenan, C. P. 1999. Aquaculture of the mud crab, genus ScyllaPast, present and future. In: Keenan, C. P. and Blackshaw, A. (Eds.), Mud crab aquaculture and biology, Proceedings of an international scientific forum, 21-24 April 1997. 
ACIAR proceedings, vol. 78, ACIAR, Canberra, Australia, p. 9-13.

Keenan, C. P., Davie, P. J. F. and Mann, D. L. 1998. A revision of the genus Scylla De Haan 1833 (Crustacea: Decapoda: Brachyura: Portunidae). Raffles Bull. Zool., 46(1): 217-245.

Li, S., Zeng, C., Tang, H., Li, F., Wang, G., Cheng, Y. and Lin, Q. 1999. Investigations into the reproductive and larval culture biology of the mud crab Scylla paramamosain: a research overview. In: Keenan, C. P. and Blackshaw, A. (Eds.), Mud crab aquaculture and biology, Proceedings of an international scientific forum, 21-24 April 1997. ACIAR proceedings, vol. 78, ACIAR, Canberra, Australia, p. 121-124.

Marichamy, R. and Rajapackiam. S. 1992. Experiments on larval rearing and seed production of the mud crab Scylla serrata (Forskal). In: Angell, C. A. (Ed.), The mud crab, A report on the seminar convened in Surat Thani, Thailand, 5-8 November 1991. Bay of Bengal Programme, Madras, India, p. 135-141.

Mann, D. L., Asakawa, T., Kelly, B., Lindsay, T. and Paterson, B. 2007. Stocking density and artificial habitat influence stock structure and yield from intensive nursery systems for mud crabs Scylla serrata (Forsskal, 1775). Aquac. Res., 38(14): 1580-1587. doi.org/10.1111/j.1365-2109.2006.01 626.x.

Ong, K. S. 1964. The early developmental stages of Scylla serrata Forskal reared in the laboratory. Proc. Indo-Pac. Fish.Coun., 11: 135-146.

Parado-Estepa, F. D. and Quinitio, E. T. 1999. Larval survival and megalopa production of Scylla sp. at different salinities. In: Keenan, C. P. and Blackshaw, A. (Eds.), Mud crab aquaculture and biology, Proceedings of an international scientific forum, 21-24 April 1997. ACIAR proceedings, vol. 78, ACIAR, Canberra, Australia, p. 174-177.

Parado-Estepa, F. D., Quinitio, E. T. and Rodriguez, E. M. 2015. Mud crab nursery rearing practices. In: Quinitio, E. T., Parado-Estepa, F. D., Thampi Sam Raj, Y. C. and Mandal, A. (Eds.), Proceedings of the International Seminar-workshop on mud crab aquaculture and fisheries management, 10-12 April 2013. Rajiv Ggandhi Centre for Aquaculture, Marine Products Export Development Authority, Govt. of India, Tamil Nadu, India, p. 89-92.

Quinitio, E. T. and Parado-Estepa, F. D. 2000. Transport of Scylla serrata megalopa at various densities and durations. Aquaculture, 185: 63-71. DOI: 10.1016/S00448486(99)00334-8.

Quinitio, E. T. and Parado-Estepa, F. D. 2003. Biology and hatchery of mud crabs Scylla spp. Aquaculture extension manual No. 34, $1^{\text {st }}$ edn. SEAFDEC Aquaculture Department, Iloilo, Philippines, 47 pp.

Quinitio, E. T. and Parado-Estepa, F. D. 2008. Biology and hatchery of mud crabs Scylla spp. Aquaculture extension manual No. 34, $2^{\text {nd }}$ edn. SEAFDEC Aquaculture Department, Iloilo, Philippines, 47 pp.

Quinitio, E. T., Parado-Estepa, F. D., Millamena, O. M., Rodriguez, E. and Borlongan, E. 2001. Seed production of mud crab Scylla serrata. Asian Fish. Sci., 14: 161-174.

Rodriguez, E. M., Quinitio, E. T., Parado-Estepa, F. D. and Millamena, O. M. 2001. Culture of Scylla serrata megalopa in brackishwater ponds. Asian Fish. Sci., 14(2): 185-189.

Rodriguez, E. M., Parado-Estepa, F. D. and Quinitio, E. T. 2007. Extension of nursery culture of Scylla serrata (Forsskål) juveniles in net cages and ponds. Aquac. Res., 38(14): 1588-1592. DOI: 10.1111/j.1365-2109.2007.01725.x.

SEAFDEC/AQD, ACEMODE/SPPI, ACELT, BFAR, ACIAR/ CATP 2010. Mud crab nursery in ponds. Aquaculture Extension Manual No. 47, SEAFDEC Aquaculture Department, Iloilo, Philippines, 27 pp.

Thampi Sam Raj, Y. C., Mandal, A., Kumaran, G., Sethuramalingam, A., Srinivasan, P. and Kumar, J. 2015. Status of mud crab industry in India. In: Quinitio, E. T., Parado-Estepa, F. D., Thampi Sam Raj, Y. C. and Mandal, A. (Eds.), Proceedings of the International SeminarWorkshop on Mud Crab Aquaculture and Fisheries Management, 10-12 April 2013. Rajiv Gandhi Centre for Aquaculture, Marine Products Export Developement Authority, Govt. of India, Tamil Nadu, India, p. 17-26.

Webley, J. A. C., Connolly, R. M. and Young, R. A. 2009. Habitat selectivity of megalopa and juvenile mud crabs (Scylla serrata): implications for recruitment mechanism. Mar. Biol., 156: 891-899. DOI: 10.1007/s00227-009-1134-0.

Williams, M. J. and Primavera, J. H. 2001. Choosing tropical portunid species for culture, domestication and stock enhancement in the Indo-Pacific. Asian Fish. Sci., 14: 121-142.

Williams, G. R., Wood, J., Dalliston, B., Shelley, C. C. and Kuo, C. 1999. Mud crab (Scylla serrata) megalopa larvae exhibit high survival rates on artemia-based diets. In: Keenan, C. P. and Blackshaw, A. (Eds.), Mud crab aquaculture and biology, Proceedings of an international scientific forum, 21-24 April 1997. ACIAR proceedings, vol. 78, ACIAR, Canberra, Australia, p. 131-140. 